Article

\title{
Experimental Model Development of Oxygen-Enriched Combustion Kinetics on Porous Coal Char and Non-Porous Graphite
}

\author{
Gyeong-Min Kim ${ }^{1,+}$, Jong-Pil Kim ${ }^{1,+}$, Kevin Yohanes Lisandy ${ }^{1}$ and Chung-Hwan Jeon ${ }^{1,2, *}$ \\ 1 School of Mechanical Engineering, Pusan National University, Busan 46241, Korea; \\ Energy_min@pusan.ac.kr (G.-M.K.); kjfeel@pusan.ac.kr (J.-P.K.); Kevinlie23@pusan.ac.kr (K.Y.L.) \\ 2 Pusan Clean Coal Center, Pusan National University, Busan 46241, Korea \\ * Correspondence: chjeon@pusan.ac.kr; Tel.: +82-51-510-3051; Fax: +82-51-510-5236 \\ + These authors contributed equally to the work.
}

Received: 28 August 2017; Accepted: 15 September 2017; Published: 18 September 2017

\begin{abstract}
The effect of oxygen-enriched air on low-rank coal char combustion was experimentally investigated. In this work, a coal-heating reactor equipped with a platinum wire mesh in the reaction chamber was used to analyze the combustion temperature, reaction time, and reaction kinetics. Increasing the oxygen content of the primary combustion air increased the combustion temperature and decreased the reaction time. As the oxygen content increased from $21 \%$ to $30 \%$, the average temperature increased by $47.72 \mathrm{~K}$ at a setup temperature of $1673 \mathrm{~K}$, and the reaction time decreased by $30.22 \%$ at the same temperature. The graphite sample exhibited similar trends in temperature and reaction time, although the degree of change was smaller because the pores produced during char devolatilization expanded the active surface available for oxidation of the char sample. A mathematical model was used to define the intrinsic kinetics of the reaction. As the oxygen content increased from $21 \%$ to $30 \%$, the reaction rate of the low-rank coal char increased. These results were also compared with those of the graphite sample.
\end{abstract}

Keywords: combustion; oxygen enrichment; low-rank coal char; char oxidation; reaction kinetics

\section{Introduction}

Coal is used to generate electricity in coal-fired power plants, despite it being an old technology, due to its abundance and low cost. However, almost half of reserves in the world are low-rank coal, and there is a policy burden due to the high price of high-rank coal. Therefore, in recent years several efforts have been made to develop technologies for utilizing the relatively inexpensive low-rank coal [1,2].

Drying and dewatering technologies for low-rank coal have been reported by many researchers. Both evaporative drying technologies such as rotary drying, fluidized-bed drying, and hot-oil-immersion drying, and non-evaporative drying technologies, such as the hydrothermal dewatering, mechanical/thermal dewatering, and solvent extraction have been studied to enable the utilization of low-rank coal as a high-efficiency energy resource [3]. Various reaction models have been suggested to improve the combustion of low-rank coal [4,5]. A wire-heating reactor was used to measure the temperature of low-rank coal char, and a spot-ignition model was suggested for the evaluation of the intrinsic reaction kinetics and the prediction of the ignition temperature [6]. A pressurized wire-heating reactor was also used to predict the gasification kinetics of low-rank coal char in a $\mathrm{CO}_{2}$ atmosphere. The study indicated that the reaction kinetics were affected by elevated pressure (up to $30 \mathrm{~atm}$ ) and high temperature (up to $1723 \mathrm{~K}$ ) [7]. However, single particle measurements of coal char ignition temperature or gasification reaction kinetics cannot provide small 
particle size char measurements (e.g., 75-90 $\mu \mathrm{m}$ ); therefore, a method utilizing wire-mesh was used in this study. A pressurized wire-mesh reactor was also utilized in several studies for measuring the kinetics of different gasification reactions (e.g., reactions with $\mathrm{O}_{2}, \mathrm{CO}_{2}$, and $\mathrm{H}_{2} \mathrm{O}$ ) [3,6,7]. An attempt was made to study the use of sodium ions as an effective catalyst for the gasification of low-rank coal. The experimental results showed that the heat treatment of low-rank coal can thermochemically affect the gasification rate via carbon conversion [8].

On the other hand, oxy-fuel and oxygen-enriched combustion of pulverized coal have been studied in order to improve the efficiency while reducing emissions in coal-fired power plants. Several studies on oxy-fuel combustion have found it to be a promising technology for capturing $\mathrm{CO}_{2}$ from power plants. The researchers reported combustion fundamentals and modeling under oxy-fuel conditions, including the combustion physics and chemistry [9]. In addition, the effect of the $\mathrm{CO}_{2}$ gasification reaction on coal char combustion under oxy-fuel conditions was simulated. The results showed that the gasification reaction was affected by both the char burnout time and the relative carbon consumption [10]. Oxygen-enriched combustion, which enhances the energy efficiency and reduces emissions, has also been reported by many researchers as an emerging technology for more efficient power generation [11,12]. The combustion kinetics of coal chars in an oxygen-enriched atmosphere were studied [13-15]. The results showed that under these conditions, the char combustion temperature increased and the char burnout time was reduced [15]. Natural gas combustion systems can also use oxygen-enriched air. In order to investigate the heating rate, emissions, temperature distributions, and fuel consumption in a system with extra oxygen content, $21-30 \%$ excess oxygen was used in a gas-fired burner [16]. The effect of oxygen content in a biomass-fueled burner was also investigated. The results showed improvements in flame shape, emission reduction, and burnout for oxygen-enriched combustion using biomass as the fuel [17]. The oxygen enrichment of co-fired blended coal and biomass was studied, with experimental tests on $\mathrm{NO}_{\mathrm{x}}$ and $\mathrm{SO}_{\mathrm{x}}$ emissions and burnout in atmospheres enriched with $25-30 \%$ oxygen being conducted [18].

This study focused on the effect of oxygen-enriched air on combustion when utilizing low-rank coal as an energy source. Experiments on the combustion temperature and the reaction time were conducted using a coal-heating reactor equipped with a platinum wire mesh in the reaction chamber when the oxygen content of the primary combustion air was increased from $21 \%$ to $30 \%$. The well-established random pore model (RPM) was proposed several decades ago by Gavalas, Bhatia, and Perlmutter [19-21]. However, the work of Lisandy et al. showed that in some applications, especially when modeling the development of low-rank coal char reaction rates, significant deviations from this model were observed [22-24]. Based on these studies, the reaction kinetics of low-rank coal char under oxygen-enriched combustion conditions were analyzed. A mathematical model was established incorporating experimental thermogravimetric analysis data. The results of the analysis and experiments were compared with those obtained for graphite, which has a poor pore structure.

\section{Experimental Methods}

\subsection{Sample Preparation}

Coal particle reactions in conventional coal-fired boilers can generally be divided into two concepts: coal devolatilization and char oxidation [25]. During the devolatilization of raw coal, most of the moisture and volatile matter in the coal are removed, and the remaining particles, referred to as char, are then employed in oxidization or combustion with oxygen at sufficiently high temperatures $\left(1100-1400^{\circ} \mathrm{C}\right)$. This study focused on char combustion at high temperatures. Coal char production for the experiment was performed using the following process.

Raw low-rank coal (Indonesian sub-bituminous coal, Figure 1a, was dried for 1 day at $45^{\circ} \mathrm{C}$. The sample powder used as fuel had particle sizes of 75-90 $\mu \mathrm{m}$. After drying, the sample was heated to $1000{ }^{\circ} \mathrm{C}$ at a heating rate of $10^{\circ} \mathrm{C} / \mathrm{min}$ in a thermogravimetric analyzer (TGA701, LECO Co., St. Joseph, MI, USA) under a nitrogen atmosphere. Figure $1 \mathrm{a}, \mathrm{b}$ show the differences between the morphologies of 
the coal before and after the char production process [26]. As can be seen in Figure 1b, some pores developed in the char due to the removal of moisture and volatile matter. Figure $1 \mathrm{c}$ shows graphite powder with particles in the range of 75-90 $\mu \mathrm{m}$ to allow for a comparison with the characteristics of the char. Table 1 summarizes the results of the proximate and ultimate analyses of the raw coal, char, and graphite.

The initial specific surface area of the char was measured by the Brunauer-Emmett-Teller (BET) method using a Micromeritics ASAP 2020 device. The morphologies of the coal samples were examined by scanning electron microscopy (SEM, S3500N, Hitachi, Tokyo, Japan).
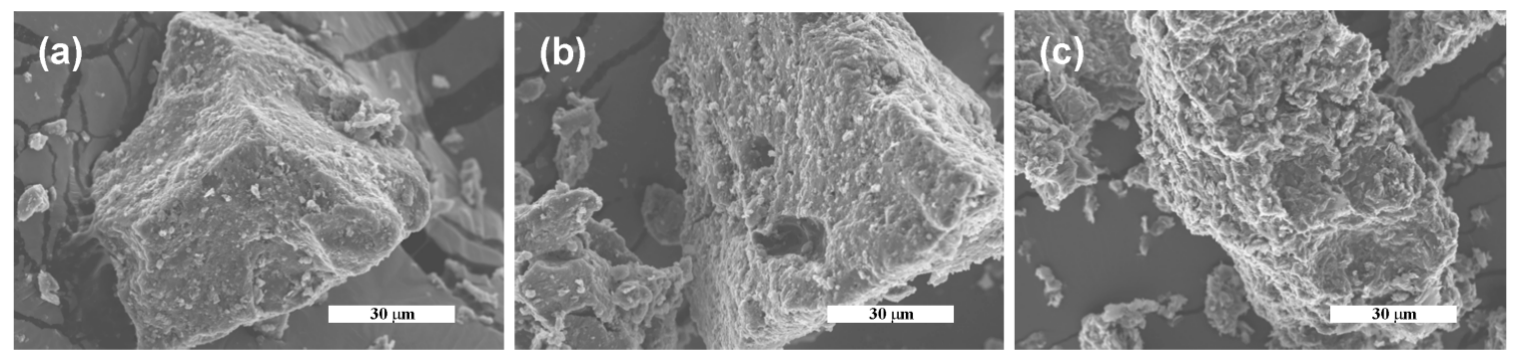

Figure 1. Scanning electron microscopy images of samples for oxygen-enriched combustion: (a) raw coal, (b) char, and (c) graphite.

Table 1. Proximate and ultimate analyses of samples.

\begin{tabular}{cccccccccc}
\hline \multirow{2}{*}{ Samples } & \multicolumn{3}{c}{ Proximate Analysis (wt \%, ad) } & \multicolumn{3}{c}{ Ultimate Analysis (wt \%, daf) } \\
\cline { 2 - 10 } & Moisture & $\begin{array}{c}\text { Volatile Matter } \\
\text { (daf) }\end{array}$ & $\begin{array}{c}\text { Ash } \\
\text { (dry) }\end{array}$ & $\begin{array}{c}\text { Fixed Carbon } \\
\text { (daf) }\end{array}$ & C & H & N & O & S \\
\hline Raw low-rank coal & 14.55 & 37.20 & 6.51 & 41.74 & 65.45 & 5.35 & 0.46 & 27.07 & 1.67 \\
Low-rank coal char & 1.84 & 2.16 & 9.15 & 86.85 & 93.26 & 0.23 & 0.42 & 5.78 & 0.31 \\
Graphite & 0.05 & 1.74 & 0.0 & 98.21 & 99.12 & 0.81 & 0.0 & 0.0 & 0.06 \\
\hline
\end{tabular}

ad: air-dry basis; daf: dry and ash-free basis; Oxygen by difference.

\subsection{Coal Heating Reactor}

The experimental setup of the coal-heating reactor for the proposed oxygen-enriched combustion is shown in Figure 2 [27]. The heating reactor can be used for combustion under high-temperature conditions of up to $1750 \mathrm{~K}$. A Pt wire mesh in the chamber was used to generate heat using a direct current (DC) electrical power supply (OPE-18100S, 4.7 kW, ODA Technologies Co., Ltd., Incheon, Korea) that was controlled using computer software. In this study, the temperatures used for coal heating were measured as 1373, 1473, 1573, and $1673 \mathrm{~K}$.

The Pt mesh (99.9\% purity) had a wire diameter of $0.04 \mathrm{~mm}$, and the wire interval was $75 \mu \mathrm{m}$. In order to obtain the combustion temperature and reaction time, a thermocouple was located at the center of the Pt mesh.

Coal char samples were loaded onto the wire mesh in a thin layer configuration, as shown in Figure 2a. Figure $2 \mathrm{~b}$ shows the heating state, in which the $\mathrm{Pt}$ mesh was heated in the coal-heating reactor. The primary reactant gas was introduced to the chamber during combustion from the atmosphere or from a mixed gas tank for the $21 \%$ and $30 \%$ oxygen conditions, respectively, and was released back into the atmosphere after combustion. 


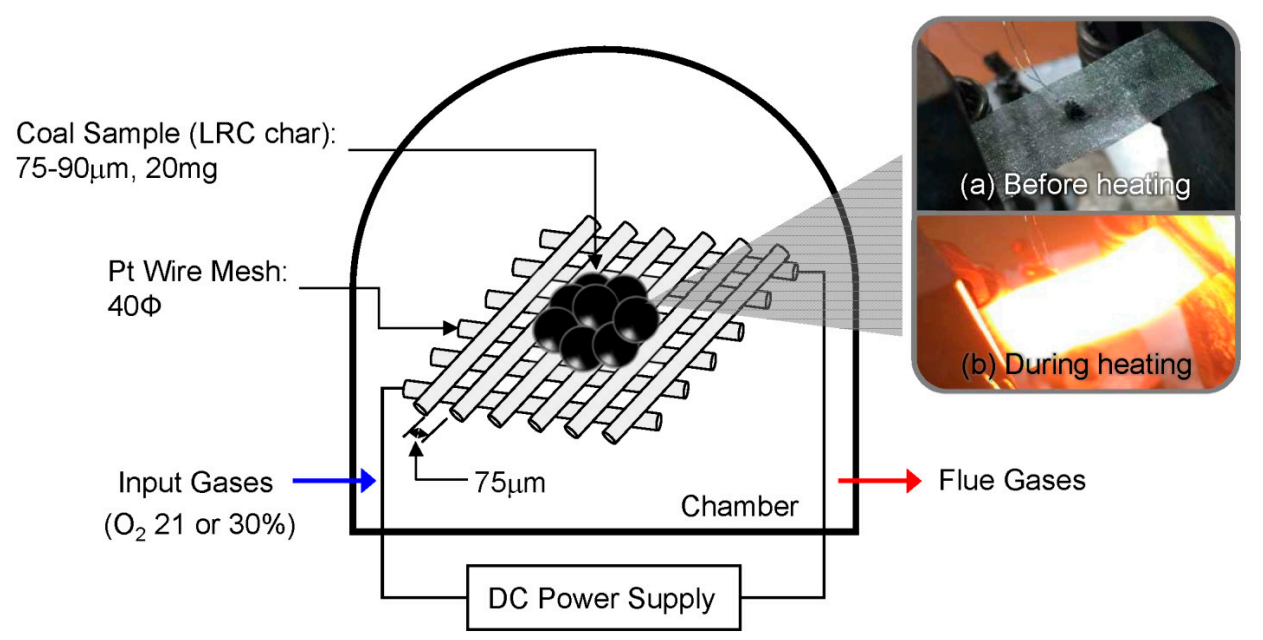

Figure 2. Schematic of the coal heating reactor. The photographs on the right show the system (a) before heating and (b) during heating.

\subsection{Numerical Methods for Kinetics}

In this study, a mathematical model was suggested for the calculation of the reaction kinetics of coal char combustion with an oxygen content of $21-30 \%$ after devolatilization. The carbon conversion ratio can be expressed as:

$$
x=\frac{m_{0}-m_{t}}{m_{0}-m_{\text {ash }}}
$$

where $m_{0}$ is the initial mass of the coal char, $m_{t}$ is the mass of the coal char at time $t$, and $m_{\text {ash }}$ is the mass of the ash content.

The apparent reaction rate $\left(R_{a p p}\right)$ is expressed as:

$$
R_{a p p}=\frac{d x}{d t}
$$

where $R_{a p p}$ is the change of carbon conversion over time.

The random pore model (RPM) is widely used to simulate changes in the micropore structure of coal char. However, when considering most low-rank coal or biomass, the random pore model does not fit well with observations. In order to achieve more accurate pore development modeling and reaction rate correlations, the Flexibility-Enhanced Random Pore Model (FERPM) proposed by Lisandy et al. was used in this study [22]. During the coal char oxidation reaction, the loss of coal char occurs rapidly. Thus, the micropore structure of the coal char also changes rapidly. In order to calculate the pore development $\left(S_{g}\right)$, the RPM and FERPM were both used in this study, and they are shown below:

$$
\begin{gathered}
\frac{d x}{d t}=k_{R P M}(1-x) \sqrt{1-\psi_{R P M} \operatorname{In}(1-x)} \\
\frac{d x}{d t}=k_{F E R P M}\left[(1-x)^{a} \sqrt{1-\psi_{F E R P M} \operatorname{In}(1-x)} \tanh (c x)+(1-x)^{b}\right]
\end{gathered}
$$

where $k_{R P M}$ and $k_{F E R P M}$ are the initial reaction rates as a function of the temperature, and $\psi_{R P M}$ and $\psi_{F E R P M}$ are the structural parameters. $a, b$ and $c$ are extra parameters for improving the accuracy of the prediction.

In order to determine the intrinsic reaction rate of the coal char oxidation $\left(R_{i n}, \mathrm{~g} / \mathrm{cm}^{2} \cdot \mathrm{s}\right)$, an $n$ th-order rate equation was used. The $n$ th-order rate equation of the global reaction can be expressed in its Arrhenius form as:

$$
R_{i n}=A_{\text {in }} \exp \left(-\frac{E_{\text {in }}}{R_{u} T_{p}}\right) P_{O_{2}, \infty}^{n}
$$


where $A_{\text {in }}$ is the intrinsic pre-exponential factor, $E_{i n}$ is the intrinsic activation energy, $R_{u}$ is the universal gas constant, $T_{p}$ is the coal char particle temperature, $P_{\mathrm{O}_{2}, \infty}$ is the partial pressure of oxygen in the ambient atmosphere, and $n$ is the reaction order, which was derived from the experimental results. This equation is defined by the reaction order and two Arrhenius parameters, $A_{\text {in }}$ and $E_{i n}$.

In order to analyze the oxidation of the coal char, the effect of the internal and external effectiveness factors should be considered. The apparent reaction rate is then expressed as [28]:

$$
R_{a p p}=\eta_{i n} \eta_{e x} S_{g} R_{i n}
$$

The internal effectiveness factor can be defined by the Thiele modulus $(\phi)$, which was developed to determine the relationship between the diffusion and the reaction rate in a microporous structure [29,30]:

$$
\begin{gathered}
\eta_{\text {in }}=\frac{1}{\phi}\left(\frac{1}{\tanh (3 \phi)}-\frac{1}{3 \phi}\right) \\
\phi=\frac{d_{p}}{2} \sqrt{\frac{(n+1) v S_{g} \rho_{p} k_{i n} R_{u} T_{p} P_{O_{2}, S}^{n-1}}{2 D_{e f f, O_{2}}}}
\end{gathered}
$$

where $d_{p}$ is the diameter of the coal char, $v$ is the stoichiometric coefficient (i.e., 0.0833 moles of $\mathrm{O}_{2}$ consumed per gram of reacted carbon), $\rho_{p}$ is the apparent density, and $D_{e f f, \mathrm{O}_{2}}$ is the effective $\mathrm{O}_{2}$ diffusion coefficient in the coal char surface.

$D_{e f f, \mathrm{O}_{2}}$ is calculated as:

$$
D_{e f f, O_{2}}=\frac{\varepsilon}{\tau} D
$$

where is the porosity, $D$ is the diffusivity, and $\tau$ is the tortuosity coefficient of the coal char pore, and its value is assumed to 1.414 [31]. The diffusivity, $D$, is calcas:

$$
D=\frac{1}{\frac{1}{D_{A B}}+\frac{1}{D_{k}}}
$$

where $D_{A B}$ is the binary diffusivity and $D_{k}$ is the Knudsen diffusivity, which is the diffusion that occurs when the diameter of the pore is comparable to or smaller than the mean free path of the gas particles involved. These diffusivities are expressed as [29-31]:

$$
\begin{gathered}
D_{k}=4580 d_{\text {pore }} \sqrt{\frac{T_{p}}{M_{A}}} \\
D_{A B}=\frac{0.02628 T^{3 / 2}}{M_{A B}^{1 / 2} \sigma_{A B}^{2} \Omega_{A B} P}
\end{gathered}
$$

where $d_{\text {pore }}$ is the diameter of the coal char pore, $M_{A}$ is the molar mass, $M_{A B}$ is the mixed molar mass of $\mathrm{A}$ and $\mathrm{B}, \sigma_{A B}$ is the particle collision diameter, $\Omega_{A B}$ is the collision integral, and $P$ is the total pressure of the system.

The external effectiveness factor $\left(\eta_{e x}\right)$ is an expression of gas transport to the boundary layer, which is the ratio of the partial pressure of the particle surface to the ambient atmosphere surrounding the coal char particle, and is expressed as:

$$
\eta_{e x}=\frac{P_{O_{2}, S}}{P_{\mathrm{O}_{2}, \infty}}
$$


The kinetic coefficients of the reaction can be considered by the linear regression method as follows:

$$
\begin{gathered}
R_{a p p}=\eta_{i n} \eta_{e x}^{n} S_{g} A_{i n} \exp \left(-\frac{E_{i n}}{R_{u} T_{p}}\right) P_{O_{2}, \infty}^{n} \\
\ln \left(\frac{R_{a p p}}{\eta_{i n} \eta_{e x}^{n} P_{O_{2}, \infty}^{n}}\right)=\ln A_{i n} S_{g}-\frac{E_{i n}}{R_{u} T_{p}} \\
\ln \left(R_{a p p}\right)=n \ln \left(\eta_{e x} P_{O_{2}, \infty}\right)+\ln \left\{\eta_{i n} S_{g} A_{\text {in }} \exp \left(-\frac{E_{i n}}{R_{u} T_{p}}\right)\right\}
\end{gathered}
$$

\section{Results and Discussion}

\subsection{Combustion Temperature and Reaction Time}

Table 2 shows the variations in combustion temperature and reaction time for low-rank coal char and graphite when the oxygen content of the primary combustion air in the coal-heating reactor was increased from $21 \%$ to $30 \%$. The experimental data are the mean value from 10 of replicate experiments and measurements. The setup temperature, or the combustion temperature during char oxidation, was set to four values. Most of the results shown in Table 2 show more significant reaction time reductions in the lower temperature region (e.g., a 35-38\% reaction time reduction at a setup temperature of $1373 \mathrm{~K}$, as compared to a $28-30 \%$ reduction at a setup temperature of $1673 \mathrm{~K}$ ).

\begin{tabular}{|c|c|c|c|c|c|c|c|c|}
\hline \multirow{2}{*}{$\begin{array}{c}\text { Samples } \\
\text { Setup } \\
\text { Temperature } \\
\text { (K) }\end{array}$} & \multicolumn{4}{|c|}{ Low-Rank Coal Char } & \multicolumn{4}{|c|}{ Graphite } \\
\hline & $\begin{array}{c}\text { Maximum } \\
\text { Temperature } \\
\text { (K) }\end{array}$ & $\begin{array}{l}\text { Reaction } \\
\text { Time (s) }\end{array}$ & $\begin{array}{c}\text { Maximum } \\
\text { Temperature } \\
\text { (K) }\end{array}$ & $\begin{array}{l}\text { Reaction } \\
\text { Time (s) }\end{array}$ & $\begin{array}{c}\text { Maximum } \\
\text { Temperature } \\
\text { (K) }\end{array}$ & $\begin{array}{l}\text { Reaction } \\
\text { Time (s) }\end{array}$ & $\begin{array}{c}\text { Maximum } \\
\text { Temperature } \\
\text { (K) }\end{array}$ & $\begin{array}{c}\text { Reaction } \\
\text { Time (s) }\end{array}$ \\
\hline 1373 & 1411.34 & 2.6 & 1420.37 & 1.6 & 1393.71 & 4.4 & 1415.30 & 2.88 \\
\hline 1473 & 1514.68 & 1.98 & 1532.83 & 1.35 & 1525.65 & 2.5 & 1539.83 & 1.68 \\
\hline
\end{tabular}
These results suggest that improved reaction rates can be achieved at lower combustion temperatures.

Table 2. Combustion temperatures and reaction time variations for oxygen-enriched combustion.

In the case of low-rank coal char at a setup temperature of $1373 \mathrm{~K}$, the difference between the maximum temperatures for oxygen contents of $21 \%$ and $30 \%$ was $9 \mathrm{~K}$. When the setup temperature was increased, this temperature difference tended to increase. The difference between the maximum temperatures was $47 \mathrm{~K}$ at a setup temperature of $1673 \mathrm{~K}$.

In comparison, graphite exhibited an identical trend to that of the low-rank coal char. In the case of graphite at a setup temperature of $1373 \mathrm{~K}$, the difference between the maximum temperatures for oxygen contents of $21 \%$ and $30 \%$ was $21 \mathrm{~K}$. Additionally, it exhibited an increase in maximum temperature of $59.06 \mathrm{~K}$ at a setup temperature of $1673 \mathrm{~K}$.

The results suggest that low-rank coal char developed a surface pore structure during the devolatilization process, and that this pore structure contributed to the combustion reaction by increasing the surface area. On the other hand, graphite, which has a carbon content of $99.21 \%$, had a poor pore structure. It therefore exhibited a slow reaction at relatively low setup temperature. However, a higher environmental temperature resulted in a more effective surface for combustion, with the oxidation reaction occurring so rapidly at the particle surface that the oxidation gas could not diffuse through the pores. For this reason, the reaction time for graphite became similar to that of low-rank coal char at temperatures around $1673 \mathrm{~K}$. 


\subsection{Reaction Kinetics}

The surface area of coal char as calculated by RPM and FERPM can be expressed as follows:

$$
\begin{gathered}
S_{g, R P M}=S_{0}(1-x) \sqrt{1-\psi_{R P M} \ln (1-x)} \\
S_{g, F E R P M}=S_{0}\left[(1-x)^{a} \sqrt{1-\psi_{F E R P M} \ln (1-x)} \tanh (c x)+(1-x)^{b}\right]
\end{gathered}
$$

An experiment was performed during thermogravimetric analysis (TGA) in order to define the structural parameters $\psi_{R P M}$ and $\psi_{F E R P M}$. Samples of $15 \mathrm{mg}$ of coal char or graphite were heated to $1273 \mathrm{~K}$ at a ramp rate of $20 \mathrm{~K} / \mathrm{min}$ under a $\mathrm{N}_{2}$ atmosphere. After remaining isothermal at $1273 \mathrm{~K}$ for $10 \mathrm{~min}$, the gas was changed to air and the samples were reacted isothermally at $1273 \mathrm{~K}$ for $30 \mathrm{~min}$. The structural parameters $\psi_{R P M}$ and $\psi_{F E R P M}$ were obtained by fitting the TGA analyses with the RPM and FERPM, as shown in Figures 3 and 4. As discussed previously, the surface areas $S_{g}$ determined in Figures 3 and 4 shows that graphite had almost no microporous structure when compared to the low-rank coal char. Moreover, the FERPM was calculated using a correction function with the optimal values of the pore development model during coal combustion, including gasification. The correlation coefficient between the experimental and fitting results using the RPM was 0.6532 for low-rank coal char, while the value for graphite was 0.8376 . The FERPM led to much higher correlation coefficients, with the value for low-rank coal char being 0.9956 , and that for graphite being 0.9980. The improvement in the fitting correlation would be very helpful for modeling purposes as predictions that are more accurate can be made using the revised model. Table 3 summarizes the calculated structural parameters $(\psi)$ and initial particle surface areas $\left(S_{0}\right)$ of low-rank coal char and graphite. The structural parameter of low-rank coal char shows a good agreement with the prediction obtained by using the equation proposed by the literature [22], which predicts that the coal with a fixed carbon content of $42 \%$ should have a structural parameter about 0.46 . However, the results for graphite, which has a carbon content of $98 \%$, did not agree with the value provided by FERPM equation, which predicted a structural parameter of around 1 . This may be due to the different fuel types used in the literature, which predicted structural changes for the thermal coal. This means that graphite was not considered in the range of fuel types used by the literature.

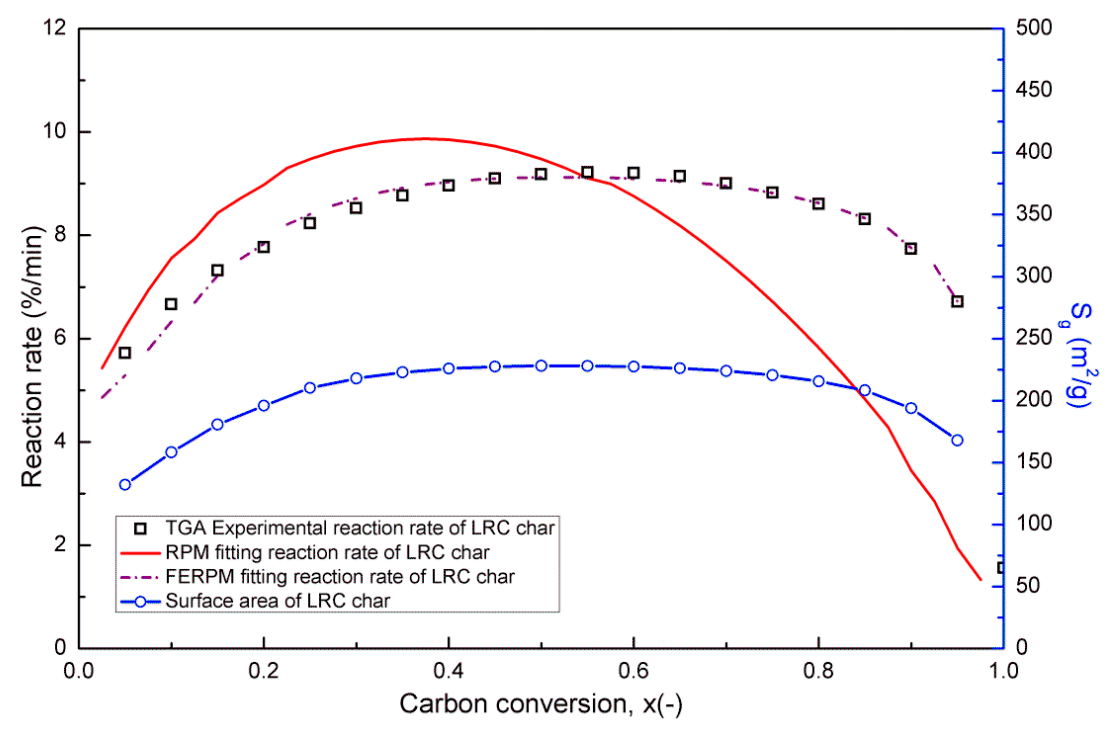

Figure 3. Char oxidation reaction rates and surface areas $\left(S_{g}\right)$ for the carbon conversion of low-rank coal char as calculated by the random pore model (RPM) and Flexibility-Enhanced Random Pore Model (FERPM) using thermogravimetric analyzer (TGA) apparatus. 


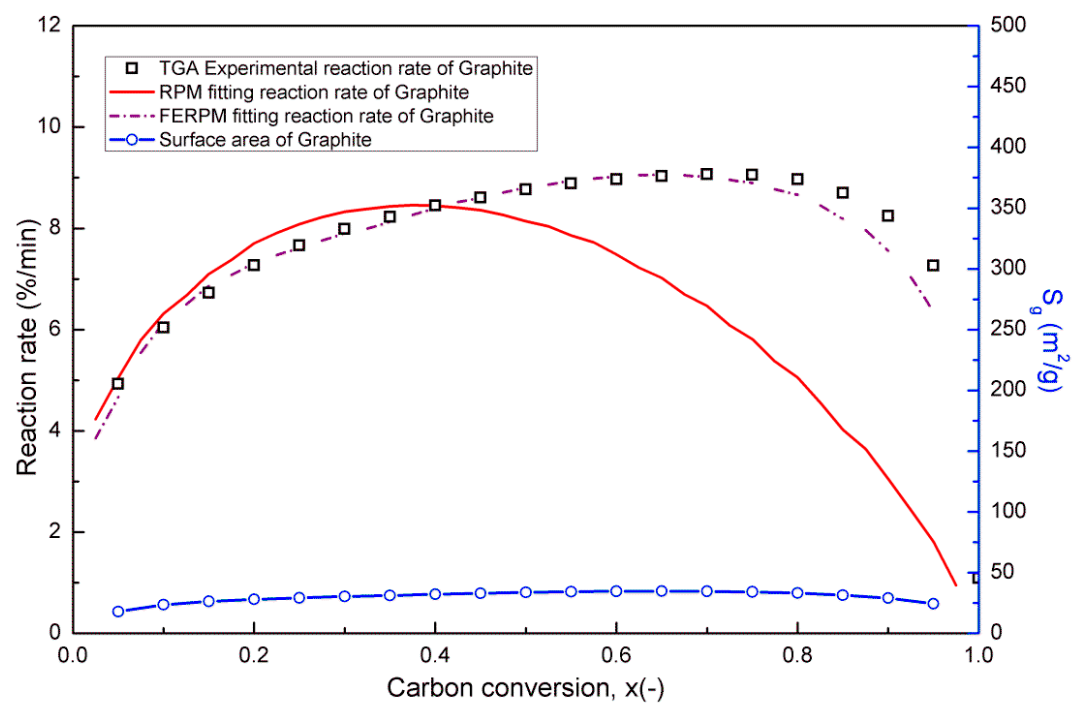

Figure 4. Oxidation reaction rates and surface areas $\left(S_{g}\right)$ for the carbon conversion of graphite as calculated by the RPM and FERPM using TGA apparatus.

Table 3. Calculated structural parameters $(\psi)$, FERPM parameters, and initial particle surface areas $\left(S_{0}\right)$ of low-rank coal char and graphite.

\begin{tabular}{ccc}
\hline Samples & Low-Rank Coal Char & Graphite \\
\hline Structural parameter $\left(\psi_{R P M}\right)$ & 23.63 & 32.99 \\
Structural parameter $\left(\psi_{F E R P M}\right)$ & 6.81 & 17.43 \\
FERPM parameter $(a)$ & 0.38 & 0.46 \\
FERPM parameter $(b)$ & 2.40 & 6.63 \\
FERPM parameter $(c)$ & 5.53 & 12.34 \\
Initial particle surface area $\left(S_{0}\right)\left(\right.$ BET Ar adsorption, $\left.\mathrm{m}^{2} / \mathrm{g}\right)$ & 113.4201 & 12.8004 \\
\hline
\end{tabular}

The coal char surface area $\left(S_{g}\right)$ was used to determine the intrinsic reaction rate, as discussed in Equation (5). The reaction order $(n)$ can be calculated by linearly fitting the natural logarithm value of the $\eta_{e x} P_{\mathrm{O}_{2}, \infty}$ and $R_{a p p}$, as described in Equation (16), with the calculated reaction order for low-rank coal char being 0.51 and the value for graphite being 0.73 . The calculated reaction order results are presented in Figure 5.

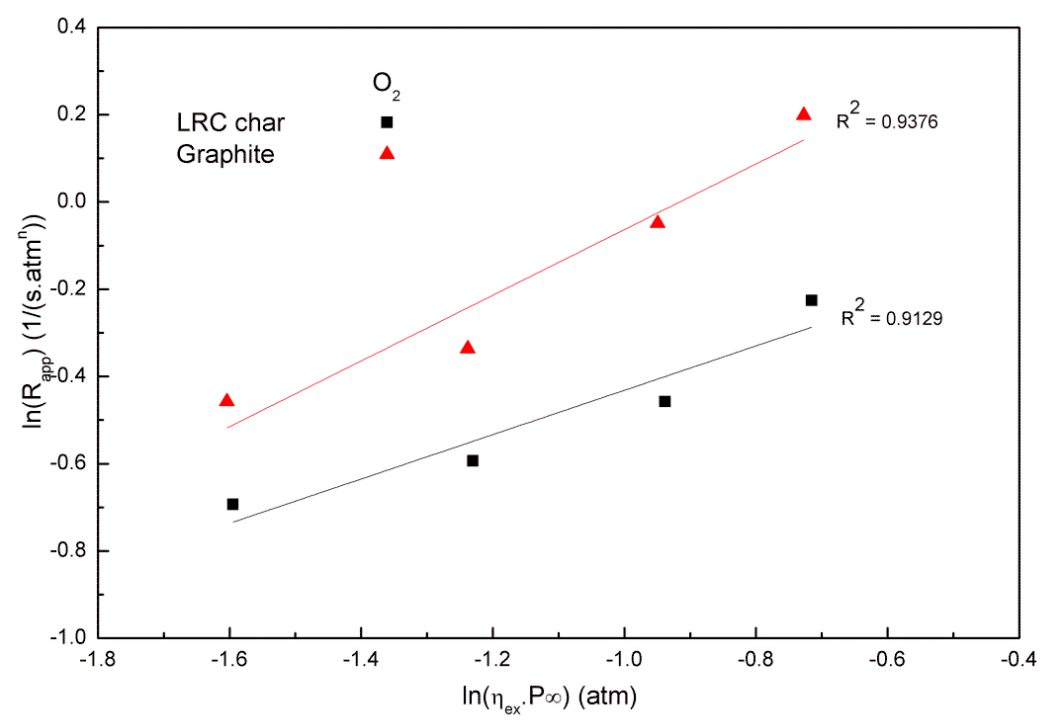

Figure 5. $n$th order Arrhenius plots for low-rank coal char and graphite. 
In order to allow for a comparison of the reaction rate constants when considering oxygen diffusion, the apparent and intrinsic kinetics are shown in Figures 6 and 7, and Table 4, calculated by the linear regression method using Equation (15). From an Arrhenius plot, Ln k versus 1/T, a linear relationship is obtained and according to Equation (15), the activation energy and the pre-exponential factor can be calculated. The results imply that the intrinsic and apparent reaction kinetics considered both internal and external effectiveness factors at ambient oxygen concentrations of $21 \%$ and $30 \%$ as the temperature increased. Low-rank coal char and graphite both showed more significant differences between their intrinsic and apparent reaction kinetics at increased temperatures. Moreover, the results suggest that the samples were diffusion controlled, with the effectiveness factors shown in Figures 8 and 9 providing evidence to support this conclusion. To evaluate the effectiveness factors obtained from the intrinsic reaction rates at high a temperature, the external effectiveness factor decreased from 1 to 0.95 , with graphite being slightly more affected by the external effectiveness factor. Meanwhile, the internal effectiveness factors decreased significantly as the temperature dropped. This implies that the reaction rates of the two samples were controlled by diffusion at high temperatures [6].

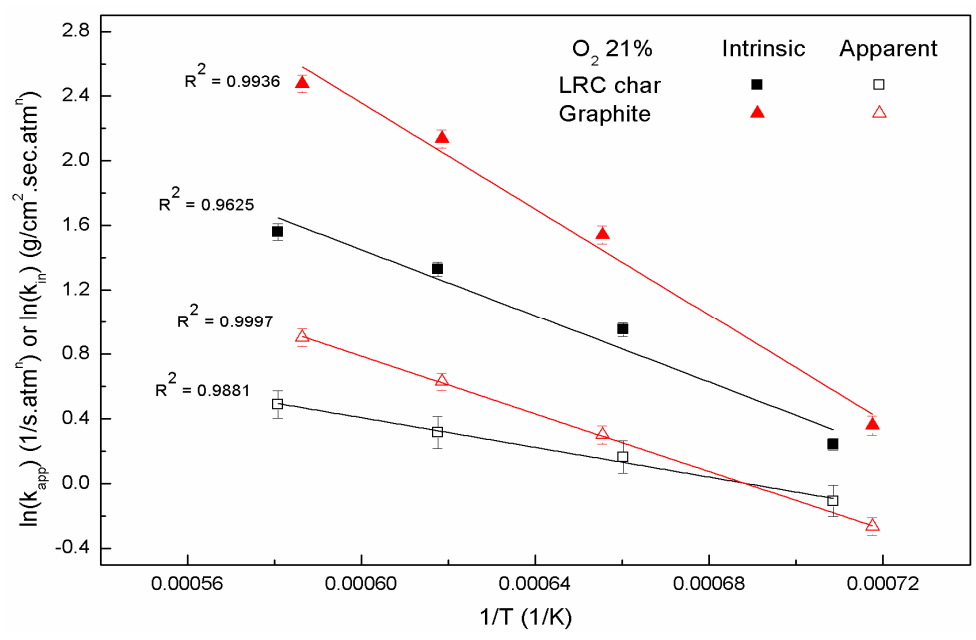

Figure 6. Comparison of reaction rate constants when considering oxygen diffusion at an ambient oxygen concentration of $21 \%$.

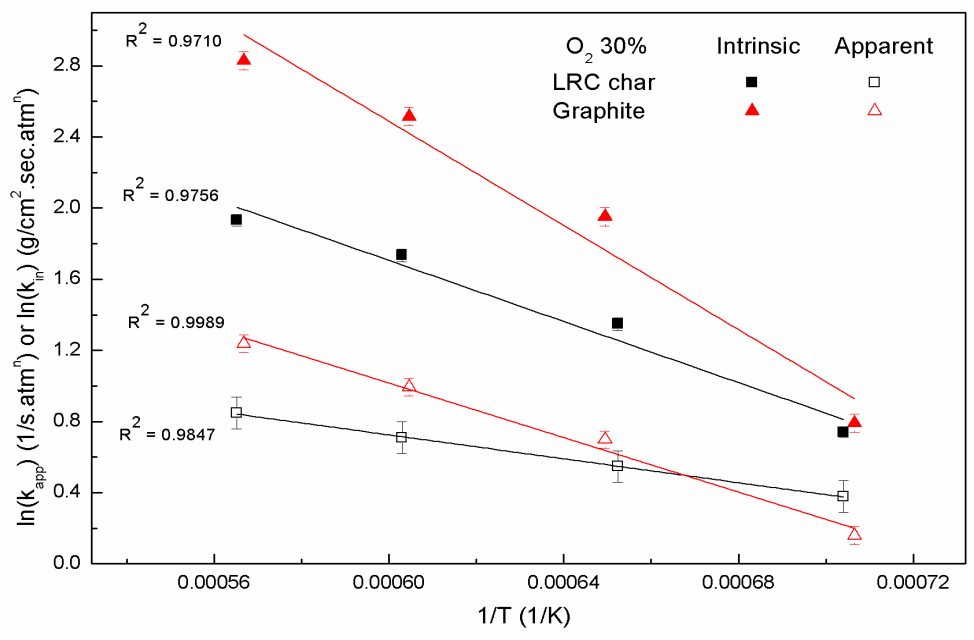

Figure 7. Comparison of reaction rate constants when considering oxygen diffusion at an ambient oxygen concentration of $30 \%$. 


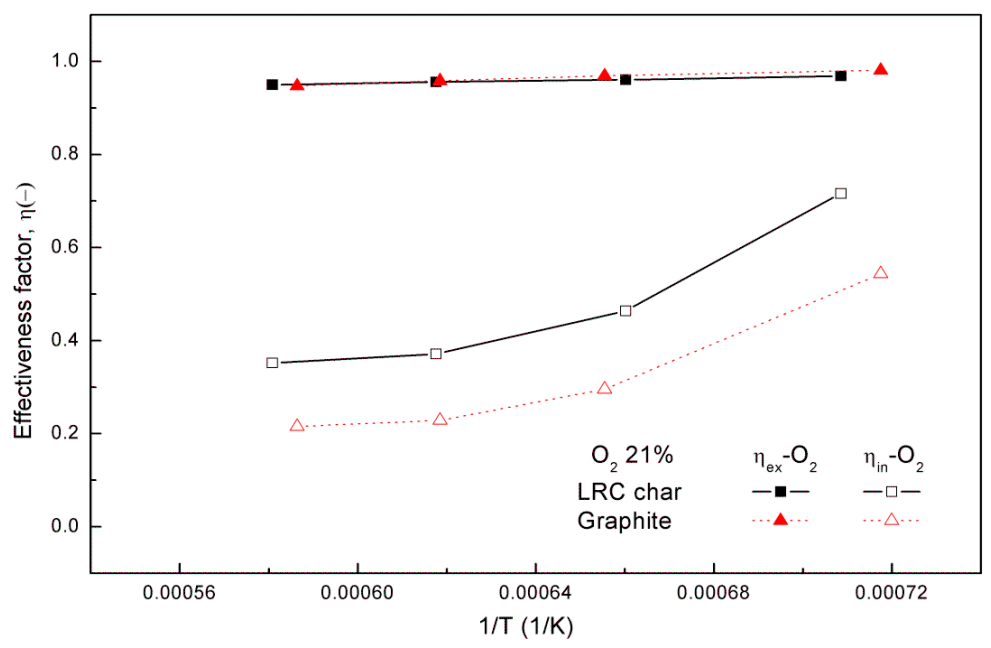

Figure 8. Effectiveness factors as a function of particle temperature at an ambient oxygen concentration of $21 \%$.

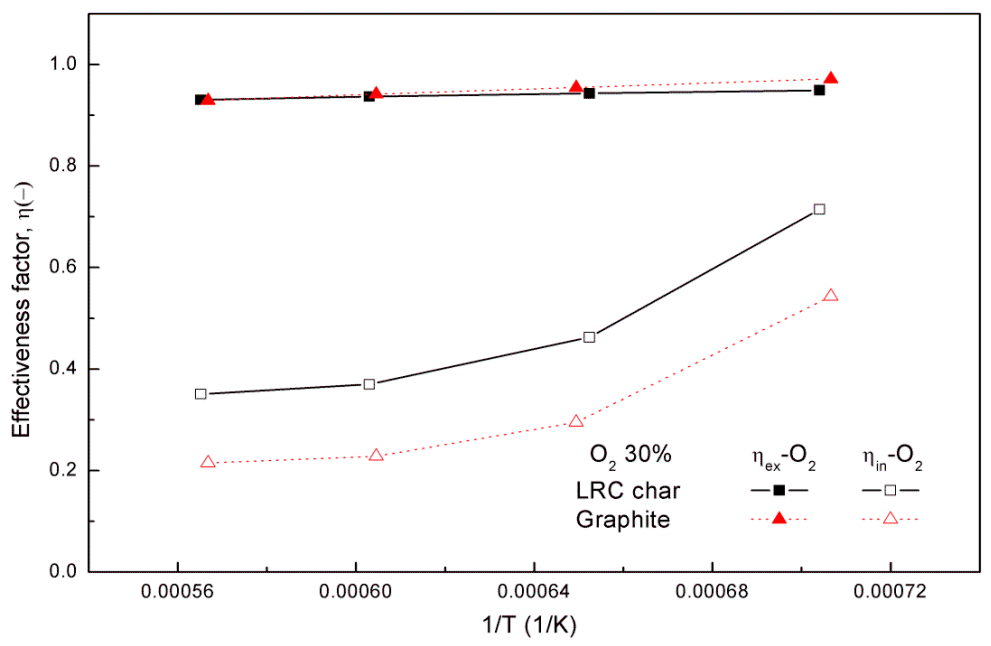

Figure 9. Effectiveness factors as a function of particle temperature at an ambient oxygen concentration of $30 \%$.

Table 4. Linear regression results for the intrinsic reaction rates expressed as $n$ th-order Arrhenius equations.

\begin{tabular}{|c|c|c|c|c|c|}
\hline \multirow{2}{*}{\multicolumn{2}{|c|}{ Samples }} & \multicolumn{2}{|c|}{ Low-Rank Coal Char } & \multicolumn{2}{|c|}{ Graphite } \\
\hline & & $\begin{array}{c}\mathrm{O}_{2} 21 \% \\
\left(\mathrm{~N}_{2} \text { Balance }\right)\end{array}$ & $\begin{array}{c}\mathrm{O}_{2} 30 \% \\
\left(\mathrm{~N}_{2} \text { Balance }\right)\end{array}$ & $\begin{array}{c}\mathrm{O}_{2} 21 \% \\
\left(\mathrm{~N}_{2} \text { Balance }\right)\end{array}$ & $\begin{array}{c}\mathrm{O}_{2} 30 \% \\
\left(\mathrm{~N}_{2} \text { Balance }\right)\end{array}$ \\
\hline \multicolumn{2}{|c|}{ Reaction order, (-) } & \multicolumn{2}{|c|}{0.5081} & \multicolumn{2}{|c|}{0.7295} \\
\hline Apparent kinetics & $\begin{array}{c}E_{a}(\mathrm{~kJ} / \mathrm{mol}) \\
\mathrm{A}\left(1 / \mathrm{s} \cdot \mathrm{atm}^{n}\right)\end{array}$ & $\begin{array}{c}38.1 \\
1.031 \times 10^{-5}\end{array}$ & $\begin{array}{c}27.9 \\
6.81 \times 10^{-6}\end{array}$ & $\begin{array}{c}74.1 \\
1.363 \times 10^{-3}\end{array}$ & $\begin{array}{c}63.7 \\
8.105 \times 10^{-4}\end{array}$ \\
\hline Intrinsic kinetics & $\begin{array}{c}E_{a}(\mathrm{~kJ} / \mathrm{mol}) \\
\mathrm{A}\left(\mathrm{g} / \mathrm{cm}^{2} \cdot \mathrm{s} \cdot \mathrm{atm}^{n}\right)\end{array}$ & $\begin{array}{c}85.5 \\
8.956 \times 10^{-4}\end{array}$ & $\begin{array}{c}71.4 \\
4.186 \times 10^{-4}\end{array}$ & $\begin{array}{c}136.6 \\
5.954 \times 10^{-1}\end{array}$ & $\begin{array}{c}121.7 \\
2.315 \times 10^{-1}\end{array}$ \\
\hline
\end{tabular}

It is apparent from the plots and the table that increasing the amount of oxygen in the atmosphere increased the burning rate in the char kinetics, in spite of the faster char combustion rates. The absolute values of the slopes of Figures 6 and 7 give the activation energies, E, and the intercepts with the y-axis provide the natural logarithms of the pre-exponential factors, A. 
In order to define the intrinsic kinetics of the reaction, a mathematical model was used. The activation energy of the low-rank coal char sample reacted at an $\mathrm{O}_{2}$ concentration of $21 \%$ was $85.5 \mathrm{~kJ} / \mathrm{mol}$, and the pre-exponential factor was $8.956 \times 10^{-4} \mathrm{~g} / \mathrm{cm}^{2} \cdot \mathrm{s} \cdot \mathrm{atm}^{n}$, whereas the low-rank coal char sample reacted at an $\mathrm{O}_{2}$ concentration of $30 \%$ had an activation energy of $71.4 \mathrm{~kJ} / \mathrm{mol}$ and a pre-exponential factor of $4.186 \times 10^{-4} \mathrm{~g} / \mathrm{cm}^{2} \cdot \mathrm{s} \cdot \mathrm{atm}^{n}$. Similarly, the activation energy of the graphite sample reacted at an $\mathrm{O}_{2}$ concentration of $21 \%$ was $136.6 \mathrm{~kJ} / \mathrm{mol}$, and the pre-exponential factor was $5.954 \times 10^{-1} \mathrm{~g} / \mathrm{cm}^{2} \cdot \mathrm{s} \cdot \mathrm{atm}^{n}$, whereas the graphite sample reacted at an $\mathrm{O}_{2}$ concentration of $30 \%$ had an activation energy of $121.7 \mathrm{~kJ} / \mathrm{mol}$ and a pre-exponential factor of $2.315 \times 10^{-1} \mathrm{~g} / \mathrm{cm}^{2} \cdot \mathrm{s} \cdot \mathrm{atm}^{n}$. Based on these results, it can be seen that increasing the oxygen concentration in combustion promoted the char reaction rate and lowered the activation energy. The intrinsic kinetics derived from the mathematical model showed the same trend as the experimental results. As the oxygen content increased, the reaction rates of both the coal char and the graphite sample increased. Thus, oxygen-enriched combustion could help to enlarge fuel range utilization so that low-rank coal, which is hardly used in coal-fired boilers, can be used as a more common fuel.

\section{Conclusions}

A coal-heating reactor was utilized for oxygen-enriched combustion with oxygen concentrations of $21-30 \%$. It consisted of a $\mathrm{Pt}$ wire mesh for generating heat from a DC power supply and a setup temperature controller. Low-rank coal char samples $(75-90 \mu \mathrm{m})$ produced from pyrolysis of the raw coal were used as fuel for char oxidation, and the experimental results were compared with those obtained by using graphite with a carbon content of $99.12 \mathrm{wt} \%$.

As the oxygen content in the reactor atmosphere was increased from $21 \%$ to $30 \%$, the combustion temperature of the low-rank coal char increased by $47.72 \mathrm{~K}$ at a setup temperature of $1673 \mathrm{~K}$, whereas the reaction time decreased by $30.22 \%$ at the same temperature. The graphite sample exhibited similar trends in combustion temperature and reaction time. This suggests that the difference between the temperature changes of the two samples at a low temperature was caused by the development of a microporous structure during the initial stage of combustion. A numerical model was chosen for calculating the reaction kinetics of the coal char in the presence of an oxygen content of $21-30 \%$.

The structural parameters used in the fitting of the low-rank coal experiment result in a good agreement between the FERPM and predictions from previous work. However, in the case of graphite, a parameter outside of the predicted range was observed. This shows that the application of the prediction model proposed in the previous work to a wider range of fuel types is improper, despite the good agreement between the result and the model when using a prediction of the fitting parameter outside of the usual range.

The activation energy of the low-rank coal char sample when reacted in an atmosphere with an oxygen content of $21 \%$ was $85.5 \mathrm{~kJ} / \mathrm{mol}$, and the pre-exponential factor was $8.956 \times 10^{-4} \mathrm{~g} / \mathrm{cm}^{2} \cdot \mathrm{s} \cdot \mathrm{atm}^{n}$. The low-rank coal char sample reacted at $30 \%$ oxygen content and had an activation energy of $71.4 \mathrm{~kJ} / \mathrm{mol}$ and a pre-exponential factor of $4.186 \times 10^{-4} \mathrm{~g} / \mathrm{cm}^{2} \cdot \mathrm{s} \cdot \mathrm{atm}^{n}$. The value of the activation energy was reduced at $30 \%$ oxygen content. Therefore, it is apparent that the reactivity of the low-rank coal char improved in a 30\% oxygen atmosphere when compared to its reactivity in a $21 \%$ oxygen atmosphere. Furthermore, the graphite sample exhibited the same trend as was seen for the experimental results for the low-rank coal char.

Acknowledgments: This work was supported by the Power Generation \& Electricity Delivery Core Technology Program of the Korea Institute of Energy Technology Evaluation and Planning (KETEP), and was granted financial resources from the Ministry of Trade, Industry \& Energy, Korea (No. 20131010101810).

Author Contributions: C.-H.J., J.-P.K. and G.-M.K. conceived and designed the experiments; G.-M.K. and J.-P.K. performed the experiments; G.-M.K., J.-P.K. and K.Y.L. analyzed the data; G.-M.K., J.-P.K. and C.-H.J. wrote the paper.

Conflicts of Interest: The authors declare no conflict of interest. 


\section{Nomenclature}

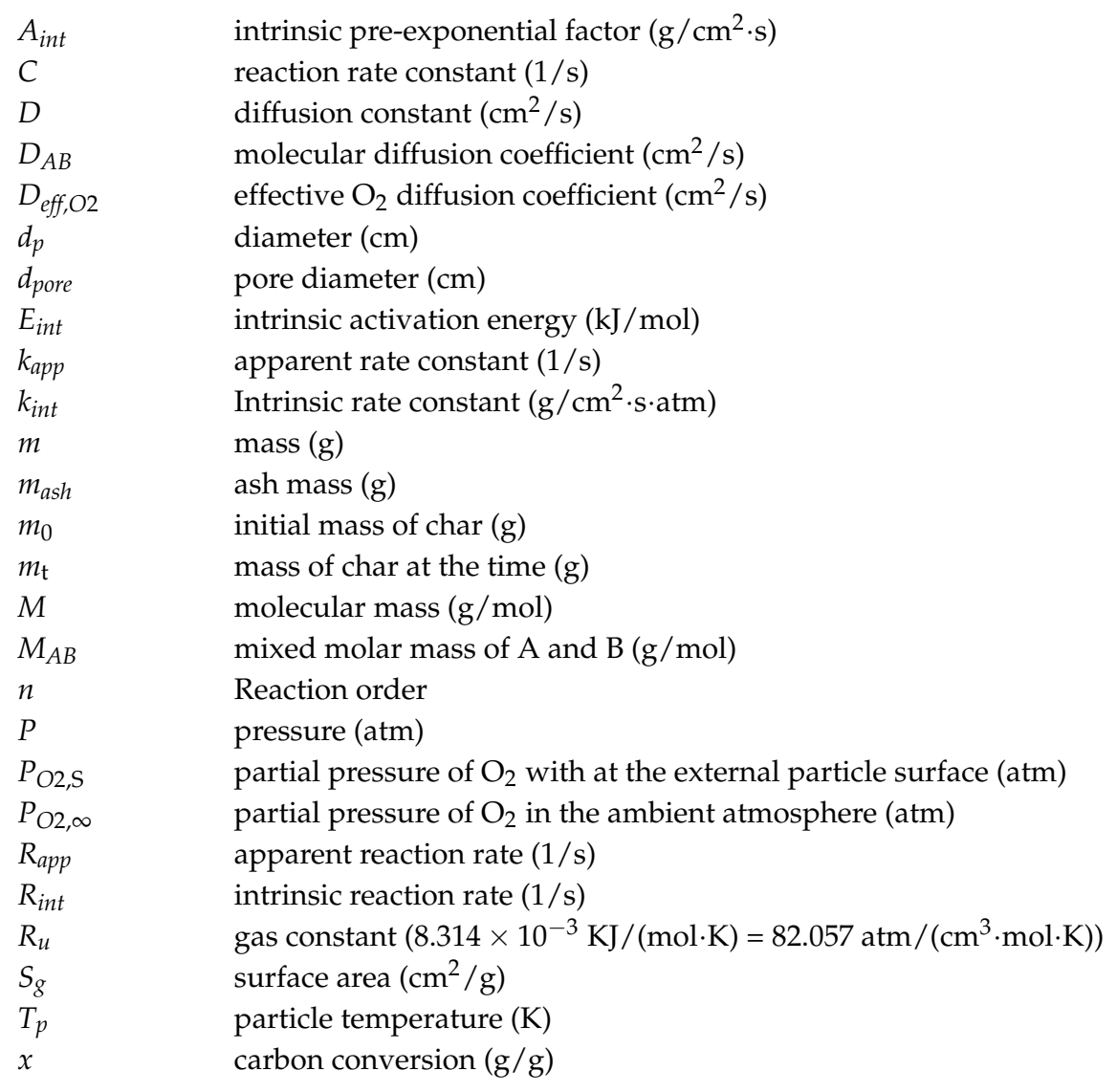

\section{Greek Symbols}

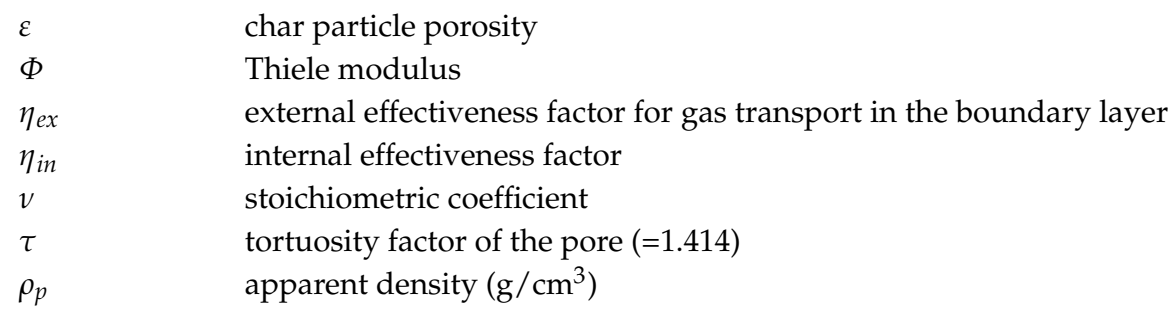

\section{References}

1. Tchapda, A.H.; Pisupati, S.V. A Review of Thermal Co-Conversion of Coal and Biomass/Waste. Energies 2014, 7, 1098-1148. [CrossRef]

2. Wang, P.; Means, N.; Shekhawat, D.; Berry, D.; Massoudi, M. Chemical-Looping Combustion and Gasification of Coals and Oxygen Carrier Development: A Brief Review. Energies 2015, 8, 10605-10635. [CrossRef]

3. Rao, Z.; Zhao, Y.; Huang, C.; Duan, C. Recent developments in drying and dewatering for low rank coals. Prog. Energy Combust. Sci. 2015, 46, 1-11. [CrossRef]

4. Hwang, M.; Song, E.; Song, J. One-Dimensional Modeling of an Entrained Coal Gasification Process Using Kinetic Parameters. Energies 2016, 9, 99. [CrossRef]

5. Wang, H.; Zhang, J.; Wang, G.; Zhao, D.; Guo, J.; Song, T. Research on the Combustion Characteristics and Kinetic Analysis of the Recycling Dust for a COREX Furnace. Energies 2017, 10, 255. [CrossRef]

6. Kim, R.G.; Jeon, C.H. Intrinsic reaction kinetics of coal char combustion by direct measurement of ignition temperature. Appl. Therm. Eng. 2014, 63, 565-576. [CrossRef]

7. Kim, R.G.; Hwang, C.W.; Jeon, C.H. Kinetics of coal char gasification with $\mathrm{CO}_{2}$ : Impact of internal/external diffusion at high temperature and elevated pressure. Appl. Energy 2014, 129, 299-307. [CrossRef] 
8. Zhang, D.K.; Poeze, A. Variation of sodium forms and char reactivity during gasification of a South Australian low-rank coal. Proc. Combust. Inst. 2000, 28, 2337-2344. [CrossRef]

9. Yin, C.; Yan, J. Oxy-fuel combustion of pulverized fuels: Combustion fundamentals and modeling. Appl. Energy 2016, 162, 742-762. [CrossRef]

10. Kim, D.H.; Choi, S.M.; Shaddix, C.R.; Geier, M. Effect of $\mathrm{CO}_{2}$ gasification reaction on char particle combustion in oxy-fuel conditions. Fuel 2014, 120, 130-140. [CrossRef]

11. Daood, S.S.; Javed, M.T.; Gibbs, B.M.; Nimmo, W. $\mathrm{NO}_{\mathrm{x}}$ control in coal combustion by combining biomass co-firing, oxygen enrichment and SNCR. Fuel 2013, 105, 283-292. [CrossRef]

12. Boushaki, T.; Merlo, N.; Chauveau, C.; Gökalp, I. Study of pollutant emissions and dynamics of non-premixed turbulent oxygen enriched flames from a swirl burner. Prog. Combust. Inst. 2017, 36, 3959-3968. [CrossRef]

13. Aziz, M.; Budianto, D.; Oda, T. Computational Fluid Dynamic Analysis of Co-Firing of Palm Kernel Shell and Coal. Energies 2016, 9, 137. [CrossRef]

14. Li, J.; Huang, H.; Huhetaoli; Osaka, Y.; Bai, Y.; Kobayashi, N.; Chen, Y. Combustion and Heat Release Characteristics of Biogas under Hydrogen- and Oxygen-Enriched Condition. Energies 2017, 10, 1200. [CrossRef]

15. Murphy, J.J.; Shaddix, C.R. Combustion kinetics of coal chars in oxygen-enriched environments. Combust. Flame 2006, 144, 710-729. [CrossRef]

16. Wu, K.K.; Chang, Y.C.; Chen, C.H.; Chen, Y.D. High-efficiency combustion of natural gas with 21-30\% oxygen-enriched air. Fuel 2010, 89, 2455-2462. [CrossRef]

17. Thornock, J.; Tovar, D.; Tree, D.R.; Xue, Y.; Tsiava, R. Radiative intensity, no emissions, and burnout for oxygen enriched biomass combustion. Proc. Combust. Inst. 2015, 35, 2777-2784. [CrossRef]

18. Pawlak-Kruczek, H.; Ostrycharczyk, M.; Czerep, M.; Baranowski, M.; Zgora, J. Examinations of the process of hard coal and biomass blend combustion in OEA (oxygen enriched atmosphere). Energy 2015, 92, 40-46. [CrossRef]

19. Gavalas, G.R. A random capillary model with application to char gasification at chemically controlled rates. AIChE J. 1980, 26, 577-585. [CrossRef]

20. Bhatia, S.K.; Perlmutter, D.D. A random pore model for fluid-solid reactions: I. Isothermal, kinetic control. AIChE J. 1980, 26, 379-386. [CrossRef]

21. Bhatia, S.K.; Perlmutter, D.D. A random pore model for fluid-solid reactions: II. Diffusion and transport effects. AIChE J. 1981, 27, 247-254. [CrossRef]

22. Lisandy, K.Y.; Kim, G.M.; Kim, J.H.; Kim, G.B.; Jeon, C.H. Enhanced Accuracy of the Reaction Rate Prediction Model for Carbonaceous Solid Fuel Combustion. Energy Fuels 2017, 31, 5135-5144. [CrossRef]

23. Lisandy, K.Y.; Kim, J.W.; Lim, H.; Kim, S.M.; Jeon, C.H. Prediction of unburned carbon and NO formation from low-rank coal during pulverized coal combustion: Experiments and numerical simulation. Fuel 2016, 185, 478-490. [CrossRef]

24. Lisandy, K.Y.; Kim, R.G.; Hwang, C.W.; Jeon, C.H. Sensitivity test of low rank Indonesian coal utilization using steady state and dynamic simulations of entrained-type gasifier. Appl. Therm. Eng. 2016, 102, 1433-1450. [CrossRef]

25. Smoot, L.D.; Smith, P.J. Coal Combustion and Gasification; Plenum Press: New York, NY, USA, 1979.

26. Guizani, C.; Jeguirim, M.; Valin, S.; Limousy, L.; Salvador, S. Biomass Chars: The Effects of Pyrolysis Conditions on Their Morphology, Structure, Chemical Properties and Reactivity. Energies 2017, 10, 796. [CrossRef]

27. Anthony, D.B.; Howard, J.B.; Hottel, H.C.; Meissner, H.P. Rapid devolatilization of pulverized coal. Symp. Int. Combust. Proc. 1975, 15, 1303-1317. [CrossRef]

28. Song, J.H.; Jeon, C.H.; Boehman, A.L. Impacts of Oxygen Diffusion on the Combustion Rate of In-Bed Soot Particles. Energy Fuels 2010, 24, 2418-2428. [CrossRef]

29. Liu, G.; Wu, H.; Gupta, R.P.; Lucas, J.A.; Tate, A.G.; Wall, T.F. Modeling the fragmentation of non-uniform porous char particles during pulverized coal combustion. Fuel 2000, 79, 627-633. [CrossRef] 
30. Kajitani, S.; Suzuki, N.; Ashizawa, M.; Hara, S. $\mathrm{CO}_{2}$ gasification rate analysis of coal char in entrained flow coal gasifier. Fuel 2006, 85, 163-169. [CrossRef]

31. Laurendeau, N.M. Heterogeneous kinetics of coal char gasification and combustion. Prog. Energy Combust. Sci. 1978, 4, 221-270. [CrossRef] 